\title{
MENINGKATKAN KEMAMPUAN PENGAMBILAN KEPUTUSAN PADA REMAJA AKHIR DENGAN MENGGUNAKAN METODE REALTY THERAPY
}

\author{
Hetty Krisnani, Rachel Farakhiyah \\ hettykrisnani@yahoo.com,rachel.farakhiyah@yahoo.co.id
}

\begin{abstract}
ABSTRAK
Usia remaja identik dengan kecerobohan dalam pengambilan keputusan. Seorang individu yang berada dalam masa remaja ini cenderung memiliki emosi yang belum stabil yang akhirnya mudah dipengaruhi oleh hal-hal internal dan eksternal dalam proses pengambilan keputusan. Pengambilan keputusan merupakan suatu proses yang melibatkan berbagai pertimbangan dan pertentangan yang terjadi sehingga terlihat dilematis di dalam diri individu untuk mengambil keputusan. Tujuan penelitian ini adalah untuk mengkaji secara lebih mendalam kefektifan penggunaan metode Reality Therapy dalam meningkatkan kemampuan seorang individu dalam menentukan suatu pilihan pemecahan masalah. Subjek penelitian adalah seorang remaja yang berusia 18 tahun dan merupakan anak asuh dalam salah satu panti asuhan di daerah Jatinangor. Metode yang diggunakan dalam penelitian ini adalah dengan melakukan sesi pendampingan selama beberapa minggu dan menggunakan pendekatan terapi realitas. Hasil penelitian menunjukan bahwa penggunaan metode Reality Therapy sangat efektif dalam meningkatkan kemampuan penentuan pilihan pemecahan masalah pada seorang remaja. Dengan menggunakan metode Reality Therapy seorang remaja terbukti mampu menghilangkan kebingungannya dalam penentuan pemecahan masalah dan akhirnya dia dapat menentukan solusi yang tepat dalam mengatasi permasalahannya.

Kata Kunci : Pengambilan keputusan, Remaja, Reality therapy
\end{abstract}

\begin{abstract}
ABSTRACK
Adolescene is identical with carelessnes in decision making. An individual who in adolescene tend to have unsatble emotion that easily influenced by external and internal things in the process of decision making. Decision making is a process that involves different considerations and conflicts that occurred so it looks like a dilemma within the individual to make decision. The prupose of this study is to examine further the effectiveness of the use of reality therapy method in improving the ability of an individual to determine a troubleshooting options. The subject is a 18year old foster child in one orphanage in Jatinangor. The method used in this research is by doing the mentoring sessions for a few weeks and using the reality therapy approach. The results showed that the use of reality therapy method is very effective in improving the capability of determining troubleshooting options on a teenager. By using reality therapy method, it is proven that a teenager able to eliminate her confusion in the determination of problem solving and eventually she can determine the rights solution to overcome the problems.

Keywords : Decision making, Adolescene, Reality Therapy
\end{abstract}

\section{PENDAHULUAN}

Masa remaja merupakan masa transisi dari masa kanak-kanak menuju masa dewasa. Dalam masa perkembangan ini banyak perubahan yang terjadi dalam diri seorang individu. Individu tersebut akan mengalami perubahan secara fisik maupun psikis. Menurut Sigmund Freud(1856-1939) dalam Sunaryo(2004:44) mengatakan bahwa fase remaja yang berlangsung dari usia 12-13 tahun hingga 20 tahun. Masa remaja merupakan masa pencarian jati diri seseorang dalam rentang masa kanak-kank sampai masa dewasa. Pada masa ini, pola pikir dan tingkah laku remaja akan berbeda jika dibandingkan dengan masa kanak-kanak. Hubungan dengan kelompok ( teman sebaya ) lebih erat dibandingkan hubungan dengan orang tua. Saat remaja mengalami ketidaksiapan dengan berbagai perubahan baik fisik, kognitif, maupun sosial, masyarakat menuntut mereka untuk membuat suatu 
pilihan atau keputusan terhadap hal-hal yang akan dilakukannya ketika ia dewasa nanti. Hal ini menyebabkann remaja mengalami dilema. Mereka mudah terpengaruh dengan budaya-budaya baru dari luar yang belum tentu budaya tersebut sesuai dengann kondisi negara kita dan mereka melakukan berbagai perilaku menyimpang akibat ketidakmampuannya dalam membuat suatu pilihan yang tepat bagi kehidupannya.

Dalam menjalankan kehidupannya setiap individu akan selalu terlibat dengan proses pengambilan keputusan, dimulai untuk hal yang dianggap sepele sampai kepada sesuatu hal yang dianggap kompleks. Pengambilan keputusan merupakan bagian dari hidup manusia dalam menghadapi berbagai masalah untuk pemenuhan berbagai kebutuhan hidupnya, sehingga setiap individu membutuhkan pengambilan keputusan yang tepat. Pengambilan keputusan merupakan suatu proses dan berlangsung dalam suatu sistem, meskipun merupakan suatu keputusan yang sifatnya paling pribadi sekalipun. Pengambilan keputusan menjadi suatu hal yang biasa diambil atau dilakukan karena individu menghadapi berbagai permasalahan untuk dapat mempertahankan hidupnya.

Dengan demikian pentingnya memiliki kemampuan dalam pengambilan keputusan . Diduga pengambilan keputusan berhubungan dengan kematangan emosi. Sehingga secara garis besar, ada dua faktor yang dapat mempengaruhi individu dalam mengambil keputusan yaitu faktor internal dan faktor eksternal. Menurut Noorderhaven (1995:46), faktor-faktor dalam diri individu yang dapat mempengaruhi individu dalam pengambilan keputusan antara lain adalah kematangan emosi, kepribadian, intuisi, dan umur.

Masa remaja indentik dengan masa emosi yang tidak stabil dan mudah terpengaruh oleh hal-hal yang ada di dalam dirinya dan hal-hal yang ada di luar dirinya maka akan mempengaruhi pada kemampuan seorang remaja dalam pengambilan keputusan. Sedangkan kemampuan dalam pengambilan keputusan yang tepat sangat diperlukan sekali dimasa ini seorang individu akan mulai dihadapi dengan berbagai macam pilihan-pilihan hidup dan mulai dihadapkan dengan berbagai masalah yang memerlukan pemilihan solusi yang tepat agar masalah dapat terselesaikan. Maka dari itu permasalahan mengenai ketidakmampuan dalam pengambilan keputusan ini merupakan sutu masalah yang penting dan perlu untuk diintervensi karena jika hal ini dibiarkkan individu tersebut akan mengalami berbagai masalah lain yang akan mengganggu kehidupan sehari-harinya.

Penyebab seorang remaja tidak mampu dalam mengambil keputusan, terutama remaja akhir dapat mengarah pada paternalisme di mana kaum dewasa melindungi para remaja dari konsekuensi penilaian mereka yang keliru. Sikap yang seperti ini cenderung membatasi hak-hak remaja dan menerapkan stigma pada remaja. Dalam pandangan paternalistik, remaja tidak boleh diberi hak untuk mengatur tindakan mereka sendiri. remaja dipandang sebagai masalah daripada sebagai sumber daya.

Untuk meningkatkan kemampuan individu dalam pengambilan keputusan dalam penelitian ini digunakan metode reality therapy. Terapi realitas adalah suatu bentuk terapi kognitif-behavioral yang dikembangkan oleh Dr. William Glasser, seorang psikiater, pada tahun 1965 (Seligman \& Reichenberg, dalam Gladding, 2004).Reality therapy menyatakan bahwa pembelajaran manusia merupakan proses seumur hidup yang didasarkan pada pilihan. Hal ini disebut teori pilhan (choice theory). Glasser menyatakan bahwa manusia bebas memilih untuk menentukan dua hal pada dirinya sendiri, yaitu memilih bagaimana akan berpikir dan memilih bagaimana akan bertindak. Reality therapy menggunakan 
sistem WDEP sebagai cara untuk membantu klien menggunakan teknik terapi dan melihat perkembangan terapi. W singkatan dari wants, artinya apa yang diinginkan klien. D singkatan dari direction (arah). Pada tahap ini, klien mengeksplorasi lebih jauh arah hidup mereka. E singkatan dari evaluation, inti reality therapy. Praktikan membantu klien mengevaluasi perilaku klien selama ini dan seberapa jauh klien bertanggung jawab atas perilaku tersebut. $\mathrm{P}$ singkatan dari plan (rencana). Pada tahap terakhir ini, klien berkonsentrasi dalam merancang rencana untuk mengubah perilakunya

\section{METODE}

\section{A. Pendekatan Penelitian}

Dalam proses penelitian ini peneliti melakukan proses pendampingan dengan seorang klien selama beberapa minggu. Praktikan mencoba untuk membantu dan memantau keadaan klien dari tahap awal sampai pada tahap akhir sesi pendampingan dalam mengatasi permasalahannya. Dalam proses pendampingan ini metode terapi yang digunakan adalah metode reality therapy. Reality Therapy merupakan salah satu metode yang berguna dalam memunculkan pilihan pemecahan masalah bagi subjek penelitian. Membangun hubungan dengan subjek penelitian; Mengeksplorasi masalah secara mendalam; Eksplorasi solusi untuk memecahkan masalah; Menerapkan solusi dengan komitmen; dan juga dalam Penerapan 14 prinsip Reality Therapy terhadap subjek penelitian.

\section{B. Subjek Penelitian}

Subjek penelitian (Klien) adalah seorang mahasiswa semester 2 Jurusan Sastra Sunda dan berusia 18 tahun yang merupakan anak asuh dari salah satu panti asuhan di daerah Jatinangor. Remaja tersebut sedang mengalami kebingungan dalam menentukan pilihan solusi yang tepat untuk menyelesaikan permasalahan yang sedang ia alami. Permasalahan yang sedang ia alami yaitu dia merasa tidak nyaman tinggal di panti asuhan tersebut. Dia tinggal di panti asuhan semenjak dia masuk kuliah. Setelah merasakan tinggal di panti selama setengah tahun dia merasa bahwa terlalu banyak peraturan di panti yang terkadang memberatkannya yaitu salah satunya adalah peraturan di panti yang membatasi berbagai macam kegiatan di luar panti. Hal tersebut menyebabkan klien tidak dapat mengikuti kegiatan-kegiatan ekstrakulikuler di kampus. Selain itu dia sering merasa jengkel dengan sikap anak-anak panti karena susah untuk diatur dan susah untuk dinasehati. Faktorfaktor tersebut yang membuat klien ingin pindah dari panti namun dia masih mengalami kebingungan untuk menentukan solusi yang tepat dalam mengatasi permasalahan ini dan belum berani untuk menentukan keputusan.

\section{Tahap-Tahapan Penelitian}

Tahap-tahapan yang dilakukan dalam proses penelitian yaitu sebagai berikut:

\section{Proses Awal Penentuan Kasus}

Penentuan kasus dilakukan dalam beberapa tahapan sebelum pada akhirnya ditentukan secara bersama mengenai kesepakatan tipe kasus dan penanganan apa yang kemudian akan ditindaklanjuti bersama-sama diantara peneliti dengan klien . Pada awal pertemuan, praktikan melakukan engagement dengan klien. Dalam engagement tersebut peneliti mulai membuka sesi dengan mengobrol pada umumnya. Dimulai dengan menanyakan kelebihan, kekurangan, masalah yang sedang dihadapi dan aspek-aspek yang ingin dikembangkan. Setelah melakukan proses tersebut dapat disimpulkan bahwa klien memiliki suatu masalah yaitu tidak mampu menentukan pilihan solusi yang tepat dalam 
mengatasi permasalahnnya. Akhirnya praktikan dan klien membuat keputusan tentang masalah yang akan menjadi fokus utama dalam penelitian tersebut. Tahapan ini dilakukan pada awal-awal sesi pendampingan.

2. Tahap Assesmen

Pada tahapan assesmen ini yang praktikan lakukan adalah menggali informasi sebanyak-banyaknya tentang diri dan lingkungan klien, dengan tujuan agar praktikan dapat membuat pernyataan masalah dengan jelas, sehingga setelah dianalisis dari data yang telah didapat dari hasil assemen yang dilakukan praktikan dengan klien, hal itu akan memudahkan praktikan untuk menentukan langkah-langkah yang harus dilakukan selanjutnya. Praktikan melakukan assessmen ini dengan memberikan beberapa pertanyaan kepada klien, melakukan wawancara dengan orang-orang yang ada di sekitar klien seperti ibu panti,teman-teman di panti dan di kampus, juga dengan konseling untuk lebih menggali potensi klien dengan terus mendengarkan apa yang dikatakan oleh klien. Tahapan assesmen ini dilakukan beberapa hari karena tidak akan mendapatkan hasil yang cukup apabila hanya dilakukan selama satu hari saja dan tahapan ini harus dilakukan secara teliti karena apabila terjadi kesalahan pada tahapan ini akan mempengaruhi tahap-tahapan selanjutnya.

Pada tahap Assemen ini diperoleh data secara lebih mendalam dan holistik tentang klien dan latar belakang masalahnya. Dalam tahapan ini dihasilkan ecomap dan genogram dari klien.
Dari proses assement yang dilakukan selama beberapa hari maka dihasilkan beragam informasi tentang klien yaitu:

ABA ( klien) merupakan anak ke dua dari dua bersaudara dan dia sudah tidak memiliki ayah, karena ayahnya sudah meninggal dunia sejak ia kelas 6 SD. ABA merupakan mahasiswa baru tahun angkatan 2015 salah satu program studi/jurusan di Fakultas Ilmu Budaya Universitas Padjajaran. Menurut pengakuan teman dekatnya klien merupakan orang yang baik, rajin dalam mengerjakan tugas kuliah, kekanak-kanankan, egois, kurang percaya diri jika di depan umum, emosinya belum stabil, dan orang yang cukup humoris. Hubungan ABA dengan keluarganya baik-baik saja tidak pernah terjadi masalah atau konflik yang besar. Hubungan ABA dengan ibu dan kakak perempuannya sangat dekat dan bahkan ABA sangat ketergantungan dengan kakak dan ibunya. Maka dalam segala apapun selalu meminta persetujuan dan apabila tidak memperoleh izin maka ABA tidak akan melakukan. ABA memiliki banyak teman dan sahabat. Namun, saat ini dia sedang mengalami kebingungan dalam menentukan solusi yang tepat untuk menyelesaikan permasalahannya di panti. Setelah setengah tahun ABA tinggal di panti banyak konflikkonflik kecil yang tidak dapat dihindarkan. Dimulai dari masalah ABA dengan temannya di Panti, sering terjadi kesalahpahaman dengan ibu panti, dan ABA belum dapat beradaptasi dengan kondisi serta peraturan di panti. Faktor-faktor tersbut membuat dia merasa tidak nyaman tinggal di panti. Maka dari 
itu, dia bingung untuk memilih solusi yang tepat agar masalahnya dapat segera terselesaikan.

\section{Gambar 1. Ecomap Klien}

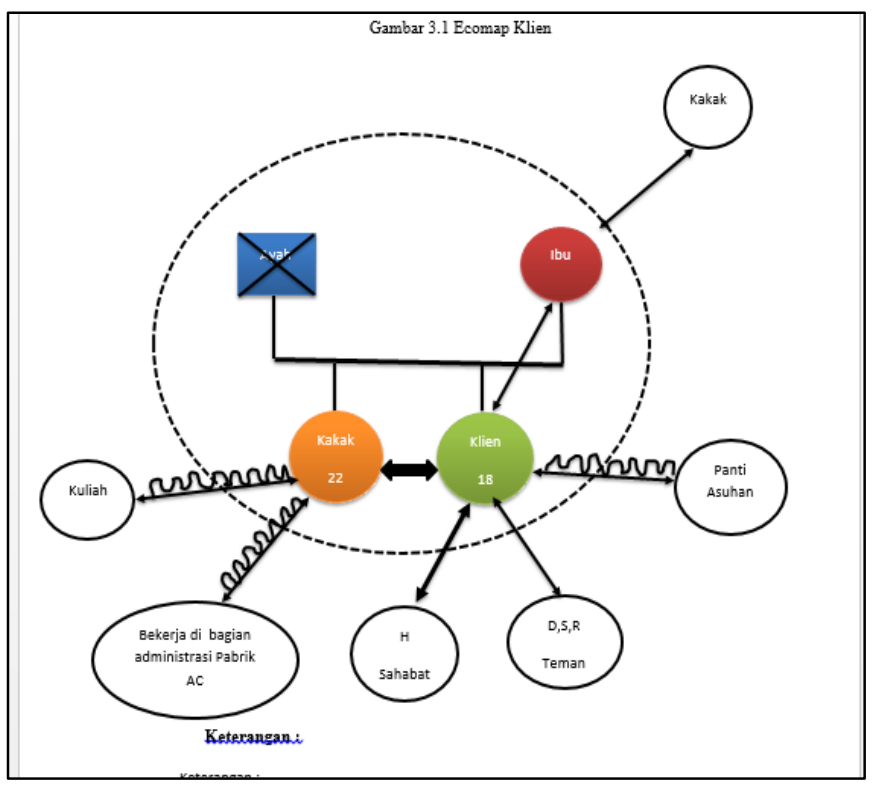

\section{Gambar 2. Genogram Klien}

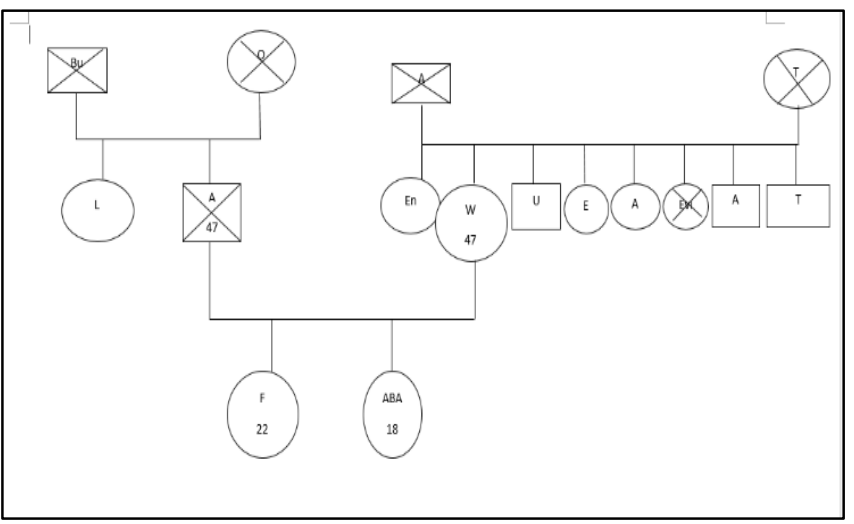




\section{Tabel 1. Catatan Masalah/Kebutuhan Klien}

\begin{tabular}{|c|c|c|c|c|}
\hline Nama & Kelebihan & Kekurangan & Masalah & $\begin{array}{c}\text { Aspek-Aspek } \\
\text { Pribadi Yang } \\
\text { Ingin } \\
\text { Dikembangkan }\end{array}$ \\
\hline \multirow{3}{*}{$\mathrm{ABA}$} & $\begin{array}{c}\text { Daya } \\
\text { ingatan } \\
\text { kuat }\end{array}$ & $\begin{array}{l}\text { Kurang percaya } \\
\text { diri }\end{array}$ & $\begin{array}{l}\text { Tidak dapat } \\
\text { menentukan } \\
\text { pilihan yang } \\
\text { tepat }\end{array}$ & $\begin{array}{l}\text { Ingin lebih percaya } \\
\text { diri jika berbicara di } \\
\text { depan umum. }\end{array}$ \\
\hline & Ramah & $\begin{array}{l}\text { Terkadang } \\
\text { suka egois dan } \\
\text { ingin menang } \\
\text { sendiri }\end{array}$ & & \\
\hline & $\begin{array}{l}\text { Suara } \\
\text { merdu }\end{array}$ & Keras kepala & & \\
\hline
\end{tabular}

Sumber: Praktikum Mikro, 2016

\section{Tahap Plan of Treatment (POT)}

Setelah melakukan tahapan assemen berarti permasalahan dan latar belakang permasalahan suda diketahui dengan jelas maka langkah selanjunya adalan rencana intervensi yang akan dilakukan untuk mengatasi permasalahan tersebut. Dalam penelitian ini permasalahan yang ditangani adalah seorang remaja yang tidak mampu menentukan pilihan solusi pemecahan masalah. Untuk mengatasi permasalahan tersebut rencana intervensi yang akan dilakukan praktikan adalah dengan menggunakan metode terapi realitas (reality therapy). Maka dari itu pada praktiknya menggunakn prinsipprinsip reality therapy. Instrumen yang digunakan dalam metode Reality Therapy yaitu dengan menggunakan from terapi realitas. Selain menentukan metode atau teknik yang akan digunakan dalam intervensi, ditentukan juga jadwal pelaksanaan dan tempat dilaksanakanya intervensi.

4. Treatment

Setelah tahapan POT( Plant of treatment) dilalui maka tahapan yang akan dilakukan selanjutnya adalah melakukan treatment. Treatment yang akan diberikan ialah dengan menggunakan metode reality terapy dengan from terapi realitas. Praktikan mendampingi dan membingbing klien dalam mengisi from terapi realitas karena dalam hal ini praktikan tidak dapat membiarkan klien mengisi dari setiap kolomnya begitu saja. Praktikan melakukan tahapan treatment ini selama dua hari yaitu:

Pada hari pertama, praktikan hanya menjelaskan tata cara pengisian from terapi realitasnya saja secara mendetail dimana klien harus memikirkan beberapa alternatif pemecahan masalahnya, dampak negatif dan dampak positif dari setiap alternatif yang dipilihnya. Hal ini dilakukan dengan maksud agar klien 
dapat mengerti maksud dan arah tujuannya sehingga pada pertemuan berikutnya sudah dapat menyelesaikan tahapan treatment dengan lancar dan hasil yang memuaskan.

Pada Hari kedua, Praktikan medampingi dan membingbing klien pada setiap pengsian kolom-kolom yang terdapat dalam from terapi realitas. Di mulai dari kolom solusi pemecahan masalah, dalam hal ini praktikan hanya bertugas mendampingi dan membingbing tidak memiliki wewenang untuk memutuskan hanya klien yang memiliki wewenang untuk memutuskan dengan memanfaatkan dari kekuatan-kekuatan yang dimilikinya. Dalam kolom alternatif pemecahan masalah ini klien memilih dua alternatif pemecahan masalah untuk menangani ketidaknyamanan tinggal di panti yaitu dia pindah atau kembali ke rumah dan dia akan tetap berada di panti. Setelah klien memiliki dua alternatif pemecahan masalah, praktikan mengarahkan klien untuk memikirkan dan mempertimbangkan kelebihan dan kekurangan dari ke dua opsi tersebut. Dalam pengisian kolom kelebihan dan kekurangan peneliti berusaha untuk menghindari sikap kliem yang beralasan dan menyalahkan orang lain. Jadi praktikan berusaha untuk mengkonfrontasi self-talk klien yang tidak efektif. Maka dari itu, pengisian from ini bukan suatu hal yang dapat diselesaikan dengan cepat karena membutuhkan proses dan pertimbangan secara matang dengan memperhatikan 14 prinsip reality therapy dalam setiap mengisi kolomnya. Setelah klien dapat menentukan kelebihan dan kekurangan dari setiap alternatif yang nantinya akan dia pilih. Tahap selanjutnya adalah tahap yang paling utama yaitu dimana klien harus dapat memutuskan solusi pemecahan masalahnya. Pada tahap ini klien perlu memikirkan dan mempertimbangkannya secara matang dengan memperhatikan kembali kelebihan dan kekurangan yang telah ia tuliskan dari kedua alternatif pemecahan masalahnya. Lalu, setelah klien merasa yakin dan sudah mengetahui keputusan yang akan dipilihnya klien memberi tahukannya kepada praktikan dan praktikan menghargai apapun solusi yang dipilih oleh klien untuk memecahkan permasalahannya.

\section{Terminasi}

Setelah melakukan treatment terhadap klien, praktikan melakukan tahapan selanjutnya yaitu terminasi. Terminasi ini dilakukan karena telah berakhirnya masa pendampingan antara praktikan dengan klien serta target minimal pada intervensi ini telah tercapai. Target minimal pada intervensi ini adalah dapat menghilangkan kebingungan klien dalam menentukan keputusan atau pilihan yang tepat untuknya dan tidak merugikan orang lain.

Setelah melakukan proses pendampingan dari awal sampai tahap akhir dalam diri klien menunjukan suatu perubahanperubahan ke arah yang lebih baik dan akhirnya dapat mencapai sesuatu yang telah ditargetkan. Jika terminasi ini telah dilakukan berarti menandakan bahwa sudah berakhirlah masa pendampingan dan praktikan memutuskan hubungan secara baik-baik dengan klien. 
6. Evaluasi

Tahapan ini merupakan tahapan akhir, tahapan ini dilakukan gunanya adalah untuk mengevaluasi proses sesi pendampingan yang telah dilakukan, klien mengevaluasi dirinya sendiri dan sikap dari praktikan selama proses pendampingan dan praktikan juga mengevaluasi sikap dari klien. Pratikan melihat apakah klien benar- benar mengalami perubahan atau tidak.

\section{HASIL PENELITIAN DAN PEMBAHASAN}

Setelah peneliti melakukan penelitian dengan klien dari mulai tahap awal sampai dengan tahap akhir maka diperoleh suatu hasil penelitian.

Tabel 2 Hasil From Reality Therapy

\begin{tabular}{|c|c|c|c|c|}
\hline \multicolumn{5}{|l|}{ 邦 } \\
\hline \multirow{2}{*}{$\begin{array}{c}\text { Keingina } \\
\text { n atau } \\
\text { masalah }\end{array}$} & \multirow[b]{2}{*}{$\begin{array}{c}\text { Solusi/tindak } \\
\text { an untuk } \\
\text { memenuhi } \\
\text { keinginan/ } \\
\text { pemecahan } \\
\text { masalah }\end{array}$} & \multicolumn{2}{|c|}{ Cek Solusi } & \multirow{2}{*}{$\begin{array}{c}\text { Solusi/tindak } \\
\text { an terpilih }\end{array}$} \\
\hline & & $\begin{array}{l}\text { KELEBIHA } \\
\mathrm{N}\end{array}$ & $\begin{array}{l}\text { KEKURANGA } \\
\mathbf{N}\end{array}$ & \\
\hline \multirow[t]{2}{*}{$\begin{array}{l}\text { Tidak } \\
\text { betah } \\
\text { tinggal di } \\
\text { Panti }\end{array}$} & $\begin{array}{l}\text { l. tetap } \\
\text { tinggal di } \\
\text { panti }\end{array}$ & $\begin{array}{l}\text { l. lebih } \\
\text { dekat } \\
\text { dengan } \\
\text { kampus } \\
\text { 2. banyak } \\
\text { teman } \\
\text { 3. } \\
\text { mendapatka } \\
\text { n uang } \\
\text { transport }\end{array}$ & $\begin{array}{l}\text { l. tidak bisa } \\
\text { bebas } \\
\text { mengikuti } \\
\text { organisasi } \\
\text { 2. sulit untuk } \\
\text { main dengan } \\
\text { teman } \\
\text { 3. jarang } \\
\text { ketemu orang } \\
\text { tua } \\
\text { 4. sering } \\
\text { merasa jengkel }\end{array}$ & \multirow[t]{2}{*}{$\begin{array}{c}\text { TETAP } \\
\text { TINGGAL DI } \\
\text { PANTI } \\
\text { ASUHAN }\end{array}$} \\
\hline & $\begin{array}{l}\text { 2. keluar dari } \\
\text { panti atau } \\
\text { kembali ke } \\
\text { rumah }\end{array}$ & $\begin{array}{l}\text { 1. lebih } \\
\text { bebas } \\
\text { mengikuti } \\
\text { organisasi } \\
\text { 2. sering } \\
\text { bertemu } \\
\text { dengan } \\
\text { orang tua } \\
\text { 3. mudah } \\
\text { untuk } \\
\text { bermain } \\
\text { dengan } \\
\text { teman }\end{array}$ & $\begin{array}{l}\text { 1. jauh dari } \\
\text { kampus } \\
\text { 2. capek pulang } \\
\text { pergi ujung } \\
\text { berung- } \\
\text { Jaitnangor } \\
\text { 3. } \\
\text { Membutuhkan } \\
\text { biaya lebih } \\
\text { 4. sering } \\
\text { merasa sendiri } \\
\text { di rumah } \\
\text { karena ibu dan } \\
\text { kakak keria. }\end{array}$ & \\
\hline
\end{tabular}

Tabel 2 merupakan tabel from terapi realitas. Praktikan memberikan dan menyuruh klien untuk mengisi from terapi realitas tersebut pada saat tahap treatment. Ketika mengisi from terapi realitas tersebut tidak hanya asal mengisi perlu ada banyak pertimbangan dan tentunya memperhatikan ke 14 prinsip reality therapy. Pada tahap awal praktikan memberikan kesempatan kepada klien untuk menentukan opsi-opsi pemecahan masalah. Dalam hal ini klien menentukan 2 pilihan solusi pemecahan masalah yang sedang ia hadapi. Setelah itu mulai mengisi kolom kelebihan dan kekurangan dari kedua pilihan solusi tersebut. Dalam hal ini praktikan membingbing klien untuk menghindari sikap yang tidak bertanggung jawab, selalu menyalahkan orang lain dan paling utama fokus pada perilakunya bukan pada perasaan. 
Setelah klien dapat menentukan kelebihan dan kekurang dari kedua pilihan solusi pemecahan masalah tersebut. Klien dapat melihat dengan jelas kelebihan dan kekurangan dari kedua pilihan solusi pemecahan masalah tersebut dan dapat mempertimbangkan solusi mana yang lebih tepat dan tidak merugikan diri sendiri serta orang lain.

Akhirnya setelah melakukan proses ini klien dapat menentukan solusi yang tepat untuk memecahkan permasalahannya yaitu dia akan tetap tinggal di panti asuhan dan akan menerima apapun konsekuensinya yaitu dia akan berusaha untuk lebih dapat beradaptasi kembali dengan kondisi dan segala aturan yang ditetapkan di panti asuhan. Setelah dapat memutuskan solusi pemecahan masalahnya klien merasa lega dan tenang karena saat ini dia tidak mengalami kebingungan lagi dan meningkatkan kemampuannya dalam menentukan pilihan pemecahan masalah yang tepat.

Decision making dapat dikatakan berhasil jika individu tidak hanya memutuskan suatu keputusan saja, namun juga melibatkan kemampuannya untuk melakukan dan mendapatkan kesempatan dari keputusan yang telah diambilnya (sitat dalam Russo \& Schoemakker, 2002). Dalam hal ini, ABA mampu untuk memutuskan keputusan untuk tetap di panti dan mencoba untuk lebih dewasa. Berbagai pertimbangan dari lingkungan sosial pun menjadi bahan pertimbangan dalam diri ABA untuk berhasil menyelesaikan permasalahannya dan memutuskan unntuk tetap tinggal di panti. Hal ini sesuai dengan yang dipaparkan oleh Russo dan Schoemaker (2002) mengenai tindakan memutuskan akan berkenaan dengan segala proses yang ada dalam pengambilan keputusan. Adanya kontrol dari lingkungan eksternal dan internal subjek penelitian mampu membuat dirinya konsisten terhadap keputusannya. Hal ini sesuai dengan teori yang dipaparkan oleh Russo dan Schoemaker (2002) yang mengatakan bahwa tindakan melakukan akan berkaitan pada aksi langsung yang dilakukan individu dalam kehidupan nyata.

Adanya kesempatan yang didapatkan individu setelah melalui tahap memutuskan dan melakukan keputusan dalam hidupnya, seperti Akan menghindari terjadinya konflik dengan ibu panti karena klien memutuskan untuk tetap tinggal di panti, tidak ada pihak yang dikecewakan atas pilihan yang di ambilnya misalnya dia tidak mengecewakan dosen yang menitipkannya di sana, tidak mengecewakan ibu,kakak dan teman dekatnya di panti. Karena apabila dia lebih memilih untuk keluar dari panti akan ada banyak orang yang ia kecewakan atas keputusannya. Meskipun dia tidak dapat mengikuti kegiatan organisasi di kampus dengan bebas tetapi ia dapat membicarakan tentang keinginannya berorganisasi tersebut kepada ibu panti atau pihak panti supaya mereka lebih memahami keinginannya dan dapat memberikan kelonggaran. Jangan menjadikan keinginan untuk berorganisasi sebagai suatu alasan. Selain itu apabila dia sering merasa jengkel kepada anak-anak panti cobalah untuk lebih beradaptasi, mengerti dan memahami sikap serta perilaku mereka karena perbuatan yang dilakukan anak panti tersebut masih dalam batasan sewajarnya saja, jadi klien sebagai orang yang lebih dewasa daripada mereka mencoba untuk memahami dan memaklumi karena pada dasarnya sikap anak kecil jahil dan menjengkelkan. Russo dan Schoemaker (2002) menjelaskan bahwa tahapan decision making tidak hanya berhenti sampai pada hasil dan penerapan keputusan yang telah di ambil diharapkan dapat memperbaiki kemampuannya dalam membuat keputusan dan menghadapi masalah yang telah dilakukan sebelumnya. Segala kegagalan dan kesuksesan baik yang berasal dari dirinya sendiri maupun orang lain diharapkan dapat 
menjadi bahan pelajaran bagi kehidupan ABA di masa yang akan datang.

Jadi intinya penggunaan metode reality therapy dengan menggunakan form terapi realitas sangat efektif untuk membantu individu meningkatkan kemampuannya dalam penentuan pilihan solusi yang tepat dalam permasalahnnya dan dapat membantu klien untuk mengontrol dirinya dalam pengambilan keputusan. Sehingga menghindari sikap terburu-buru dalam penentuan pilihan karena melalui proses pertimbangan secara matang.

\section{SIMPULAN}

Kemampuan dalam pengambilan keputusan merupakan suatu hal yang penting dimiliki oleh setiap individu. Karena dalam setiap harinya seorang individu akan dihadapi dengan berbagai macam pilihan yang harus ia putuskan. Apabila dia tidak memiliki kemampuan dalam pengambilan keputusan yang tepat maka akan mempengaruhi konsep dirinya dan akan mempengaruhi hidupnya karena dia selalu merasa gagal atau salah dalam mengambil keputusan atau mungkin merugikan orang lain. Masalah ketidakmampuan dalam pengambilan keputusan yang tepat sering dialami oleh para remaja terutama remaja akhir. Masa remaja identik dengan masa pencarian jati diri yang senangnya mencoba hal-hal baru dan memiliki rasa keakuan yang tinggi yang terkesan sulit untuk diatur. Karena hal tersebut seringkali remaja bertindak egois dan tidak memikirkan dampaknya dari setiap pilihan yang ia ambil. Praktikan menggunakan metode terapi realitas untuk meningkatkan kemampuan dalam pengambilan keputusan. Metode reality therapy ini merupakan suatu cara untuk memunculkan solusi pemecahan masalah yang tepat dengan melalui beberapa tahapan. Dari mulai membangun hubungan, mengeksplorasi masalah,mengeksplorasi solusi dan sampai dengan menerapkan solusi menggunakan 14 prinsip reality therapy. Setelah mencoba menggunakan dan menerapkan metode ini dalam penelitian peningkatkan kemampuan pengambilan keputusan dan ternyata metode ini sangat efektif untuk penentuan pilihan yang tepat. Karena klien yang awalnya bingung dalam menentukan keputusan dan selalu bergantung kepada orang lain menjadi lebih mampu dalam memetakan solusi pemecahan masalah sendiri.

\section{SARAN}

Dalam proses treatment menggunakan metode terapi realitas sebaiknya yang menjadi fokus perhatian praktikan adalah kepada rencana tindakan yang akan dilakukan oleh klien, bukan pada perilaku yang ingin dihilangkan. Selain itu dalam reality therapy lebih baik evalusi dilakukan oleh klien itu sendiri bukan praktikan. Agar klien menyadari bahwa tindakannya yang dilakukannya benar atau salah jika klien mengetahuinya maka klien akan termotivasi untuk melakukan perubahan.

Dalam hal ini apabila setelah proses pendampingan klien mengalami kekambuhan atau mengalami kebingungan kembali dalam menentukan pilihan solusi yang tepat. Karena klien sudah lebih mandiri maka apabila terjadi kekambuhan yang dilakukan oleh klien adalah menenangkan diri terlebih dahulu jangan terburu-buru ketika akan menentukan pilihan harus melalui pertimbangan yang sangat matang . Ketika sudah memikirkan dampak negatif dan positif dari setiap pilihan alternatifnya maka baru klien dapat mengambil keputusan. Dengan melakukan hal seperti itu akan membuat seorang individu lebih dapat bertanggungjawab kepada keputusan yang telah diambilnya. 


\section{UCAPAN TERIMAKASIH}

Pujii syukur dan limpah terima kasih kehadirat Allah SWT karena hanya berkat,anugerah,dan bimbinganNya sehingga penelitian guna penulisan artikel untuk memenuhi tugas dalam praktikum mikro ini dapat diselesaikan. Selanjutnya, terselesaikan penelitian dan penulisan artikel ini berkat bimbingan dan petunjuk dari tim pengajar praktikum mikro, selaku dosen pengampu mata kuliah praktikum mikro yang dengan penuh perhatian dan kesabaran telah memberikan dorongan,arahan dan koreksi sehingga menambah luas wawasan kami dalam menyempurnakan artikel ini, untuk itu saya ucapkan terima kasih. Tidak lupa kami ucapkan terima kasih kepada Pihak Yayasan Panti Sosial Asuhan Anak sebagai laboratorium penulis beserta klien yang mampu bekerja sama dengan sangat amat baik. Akhirnya kepada semua pihak yang telah membantu, secara langsung maupun tidak langsung, yang namanya tidak saya cantumkan dalam tulisan ini diucapkan terima kasih.

\section{DAFTAR PUSTAKA}

Glasser, Naomi (Editor). (1980). What Are You Doing? How People Are Helped through RealityTherapy. New York: Harper \& Row Publishers.

Gunarsa,S.D., \& Gunarsa,Y.S.D. (2006). Psikologi Perkembangan Anak dan Remaja edisi ke 4 .Jakarta: Gunung Mulia.

Ruso,J.E., \& Schoemaker,P.J.H.(2002). Winning decision: How to make the right decision the frist time.USA.

Santrock,John W. (2003). Adolescene: Perkembangan Remaja 6 Editon. Jakarta: Erlangga

Sarwono,Sarlito Wirawan. (2010). Psikologi Remaja Jakarta: Rajawali press

Widiyanti,P.R.R. (2012). Studi Kasus mengenai Decision Making untuk Keluar dari Abusive Relationship pada Remaja Akhir. Jurnal Ilmiah mahasiswa UNESA.10(3):1-7. 